\title{
Pulmonary Carcinosarcoma: A Case Report
}

\author{
Pulmoner Karsinosarkom: Bir Olgu Sunumu
}

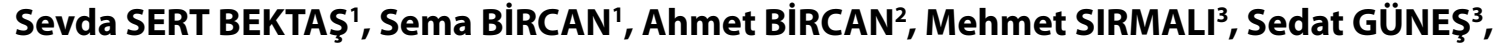 \\ Kemal K. BOZKURT' ${ }^{1}$, Tuba DEVRIM'
}

Department of ${ }^{1}$ Pathology, ${ }^{2}$ Pulmonary Diseases and ${ }^{3}$ Thoracic Surgery, Süleyman Demirel University, Faculty of Medicine, ISPARTA, TURKEY

This article has been presented as a poster at the 31st TUSAD National Meeting held at Ceşme - İzmir on October 17-21, 2009

\begin{abstract}
Pulmonary carcinosarcoma, belonging to sarcomatoid carcinomas, is a quite rare tumor that contains both malignant epithelial and mesenchymal elements. This tumor has different phenotypic characteristics and clinical course compared to non-small cell lung tumors. A case diagnosed as carcinosarcoma is presented and its clinical and pathological features and the differential diagnosis are discussed. The case was a 74-year-old male admitted with shortness of breath and cough. The chest x-ray showed a left lung mass and a bronchoscopic examination was performed. Histopathological examination of the bronchoscopic biopsy showed necrosis and a malignant tumor consisting of diffuse infiltrative anaplastic cells. Surgery was performed and the case was diagnosed as carcinosarcoma in the resection material. Pulmonary carcinosarcoma is a rare lung tumor. Determination of tumoral cells and performing advanced investigations in resection material seem to be relatively easier than in small biopsies. However, this type of tumor can be encountered in small biopsy materials as in the presented case and should be kept in mind in relation to the differential diagnosis as small tissues can have only one, particularly mesenchymal, tumoral component.
\end{abstract}

Key Words: Lung, Carcinosarcoma

\section{INTRODUCTION}

Pulmonary sarcomatoid carcinomas are differentiated from non-small cell carcinomas by their different phenotypic characteristics and clinical course and make up a separate group containing sarcomas and sarcoma-like components (1). Sarcomatoid carcinomas are quite rare and constitute approximately $0.3-1.3 \%$ of all lung tumors $(1,2)$.

Pulmonary carcinosarcoma is a rare tumor within the sarcomatoid carcinoma group and consists of a mixture of malignant epithelial and sarcomatous mesenchymal elements such as cartilage, bone or skeletal muscle $(1,2)$. It is found in the central or peripheral lung area (1). In

\section{ÖZ}

Pulmoner karsinosarkom, sarkomatoid karsinom içinde yer alan malign epitelyal ve mezenkimal elemanları bir arada içeren nadir bir tümördür. Akciğerin küçük hücreli dışı tümörlerinden farklı fenotipik özellikleri ve klinik seyri vardır. Bu yazıda karsinosarkom tanısı alan bir olgu sunulmuş, klinik ve patolojik özellikleri ile ayırıcı tanıda dikkat edilecek bulgular tartışılmıştır. Nefes darlığı ve öksürük yakınmaları ile başvuran 74 yaşında erkek hastadır. Çekilen akciğer grafisinde solda kitle saptanmış ve bronkoskopi işlemi uygulanmıştır. Bronkoskopik biyopsinin histopatolojik incelemesinde nekroz ve diffüz infiltrasyon yapan anaplastik hücrelerin oluşturduğu malign tümör görülmüştür. Olguya daha sonra cerrahi operasyon planlanmış ve yapılan akciğer rezeksiyonunda karsinosarkom tanısı almıştır. Pulmoner karsinosarkom nadir bir akciğer tümörüdür. Rezeksiyon materyalinde tümör hücrelerinin belirlenmesi ve ileri incelemeler küçük biyopsi materyaline göre nisbeten daha kolay gibi durmaktadır. Bununla birlikte sunduğumuz olguda olduğu gibi küçük biyopsi materyallerinde de bu tip tümörlerle karşılaşabileceğimizi ve bu küçük dokularda lezyonun sadece bir komponentinin ve özellikle de mezenkimal tumor komponentin olabileceğinin ayırıcı tanıda yönünden akılda tutulması gerekmektedir.

Anahtar Sözcükler: Akciğer, Karsinosarkom

general, the patients are in their 6 th or 7 th decade at the time of diagnosis and it is seen 4 times more commonly in males $(1,3)$. Its development is closely related to smoking. Cases that are a result of asbestos exposure have also been reported (4-6). The most common epithelial component is reported to be squamous cell carcinoma (\%45-70) and the mesenchymal component fibrosarcoma $(1,7)$.

We report a male case who was found to have a mass in the lower part of the left lung and received a diagnosis of carcinosarcoma in this report and discuss the clinical and pathological features and the main points of differential diagnosis for this rare tumor.

Correspondence: Sevda SERT BEKTAŞ

Department of Pathology, Süleyman Demirel University, Faculty of Medicine, ISPARTA, TURKEY

E-mail: drsevdasert@hotmail.com Phone: +90 2462112934 


\section{CASE REPORT}

Our case was a 74-year-old male patient. He had complained of a dry cough and shortness of breath for the last month and the chest $\mathrm{x}$-ray (Figure 1) had shown a lobulated contoured mass lesion in the left hilar region which resulted in a referral to our center. The only point of interest in his personal history was 40 packs-year of smoking. The physical examination revealed decreased respiratory sounds in both lungs. Routine blood chemistry values were normal. Thoracic computerized tomography (CT) (Figure 2) showed a left lung lower lobe lobulated contoured mass with heterogenous contrast enhancement, wrapped around the left lower lobe bronchus and pulmonary artery, and measuring $85 \times 77 \times 72 \mathrm{~mm}$. No mediastinal lymph nodes of pathological size were observed. Thoracic magnetic resonance imaging (MRI) did not reveal invasion of the mediastinum and main vascular structures. Bronchoscopic investigation showed a lesion obstructing left lower lobe entry and the biopsy showed necrotic tissues and adjacent pleomorphic tumoral cells with large nuclei that did not form a pattern on cytopathological examination. It was not possible to differentiate between a mesenchymal tumor and undifferentiated carcinoma as these cells were negative for pankeratin (Pan-CK) and positive for vimentin by immunohistochemistry so a diagnosis of "malignant tumor" was made and left lower lobectomy was performed.

Macroscopically the material was $7.5 \times 6.5 \times 3 \mathrm{~cm}$ in size with a smooth surface and nodular character and was partially covered with visceral pleura. The sections showed that almost all the tissue was yellow-white with a solid character and fleshy consistency and consisted of tumoral lesions which were necrotic in some areas along with pulmonary tissue in a very small area at the periphery. Microscopic investigation showed that the tumor was well demarcated from the focal lung tissue in the periphery and that it consisted of necrotic areas and atypical pleomorphic cells with large nuclei where the nucleoli could be seen in many areas. Spindle tumor cell areas and focal chondroid differentiation areas were also observed. These cells also contained epithelioid cell groups containing keratinized cells in some areas and tumoral cell groups creating glandlike structures (Figure 3A,B,C). Immunohistochemical investigation showed that the epithelioid areas were strongly positive for PanCK (Figure 4A) and epithelial membrane antigen (EMA), focally positive for CK20 and P63 and negative for CK7. The epithelial markers were negative in the other defined tumoral areas whereas vimentin was diffusely positive (Figure $4 \mathrm{~B}$ ) and S-100 was positive in chondroid areas. Smooth muscle actin (SMA) and TTF-1 results were negative. These histopathological and immunohistochemical features led to a diagnosis of carcinosarcoma. There was no lymph node metastasis and the surgical stage was T3N0M0. The patient refused further treatment and is currently well on the 9th postoperative month with no progression on CT follow-ups.

\section{DISCUSSION}

Sarcomatoid carcinomas make up a lung tumor group with five different histological subtypes showing similar clinical features consisting of pleomorphic carcinoma, spindle cell carcinoma, giant cell carcinoma, carcinosarcoma and pulmonary blastoma in the latest published histological classification of the World Health Organization. They can macroscopically be divided into two groups. Peripherally-

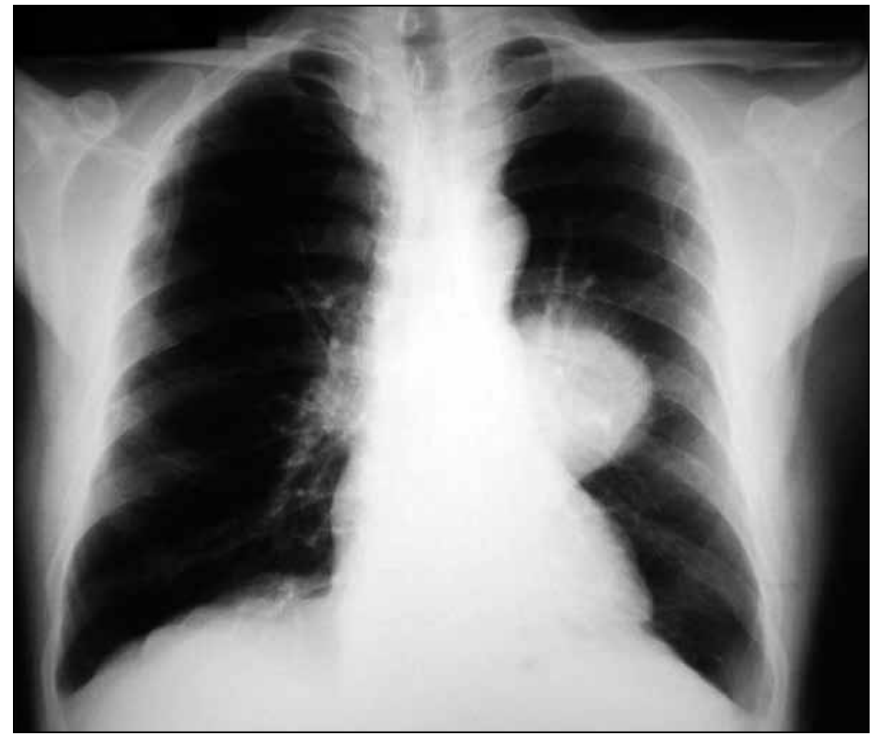

Figure 1: The chest X-ray of the case where the left hilar mass was detected.

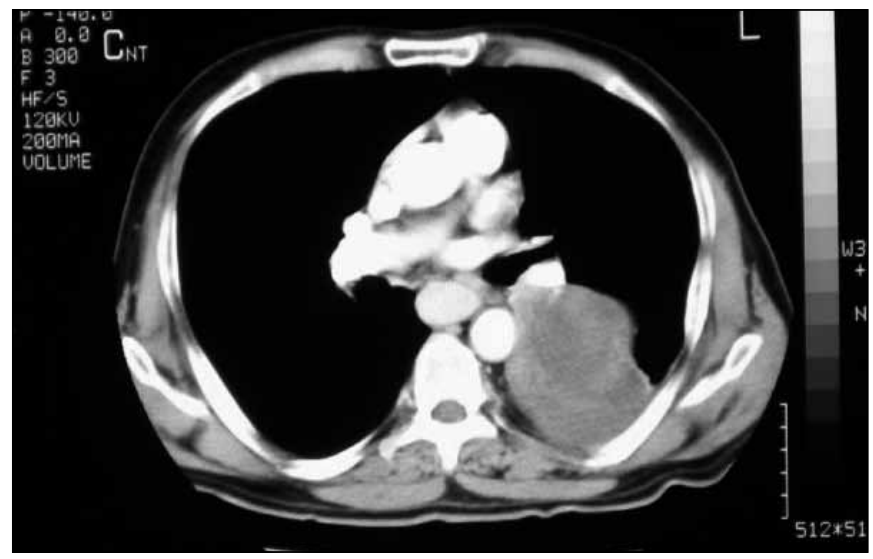

Figure 2: Left lower lobe heterogenous-density mass lesion with posterior location, compressing the thoracic anterior lobe on thoracic CT. 

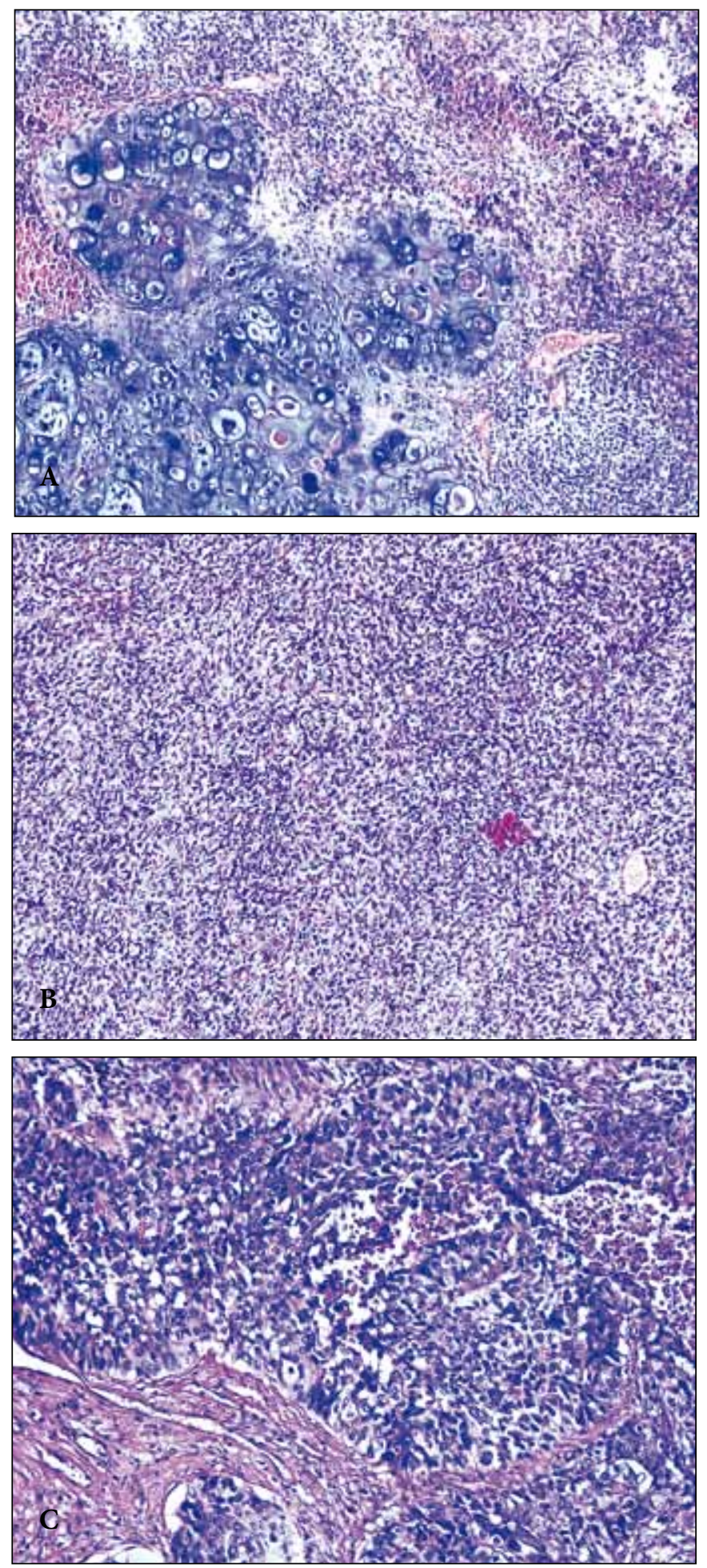

Figure 3: A) Tumor with dominant chondroid areas on the right and below, and epithelioid areas above (H\&E; x100). B) Tumor cells with marked pleomorphism and atypia (H\&E; x100). C) Areas of focal necrosis and neighboring epithelioid tumor cell groups (H\&E; x200).
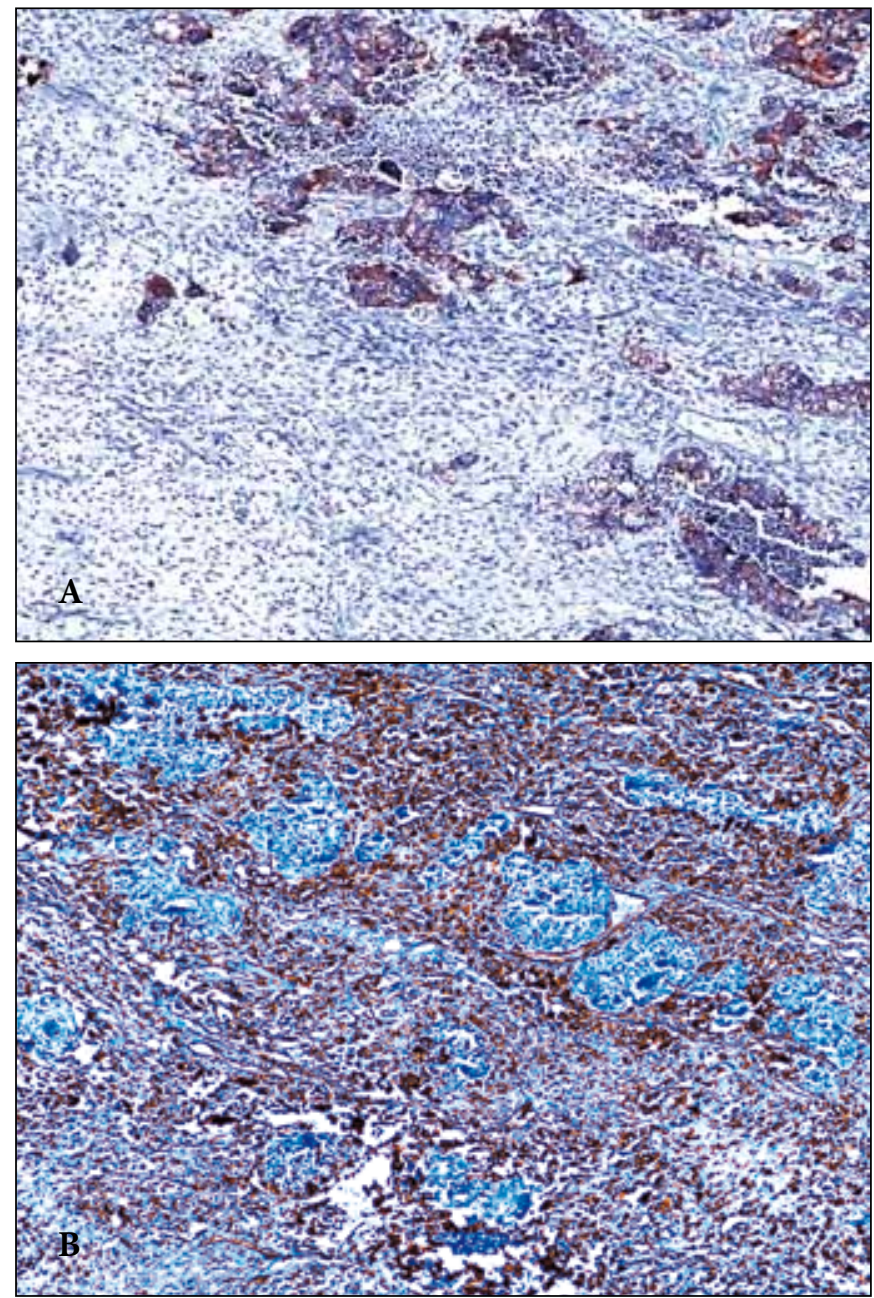

Figure 4: A) Positivity of epithelioid cell groups with pan-keratin, B) Negative epithelial cells and widespread positivity in the sarcomatous cells with vimentin (DAB; x100).

located tumors are larger than $5 \mathrm{~cm}$, and are well limited with a grey-yellow brown color. Findings such as bleeding and necrosis may be present. Tumors showing intrabronchial growth in a sessile or pedunculated manner are usually of smaller size and may show infiltration into the lung parenchyme from their attached localization (1).

Pulmonary carcinosarcomas are a quite rare sarcomatoid carcinoma type and are composed of malignant epithelial and mesenchymal components (8). They have first been described by Kika (6). The histogenesis is not clear and there are various theories. The commonly accepted view is that the epithelial and mesenchymal components are derived from the same histological origin and that the tumor is a biphasic monoclonal tumor (9). Its development is closely associated with smoking but some cases following asbestos exposure have also been reported (4-6). It is mostly seen 
in male smokers older than 50 (10). Takeda et al. (11) have reported a male to female ratio of 4:1 while this ratio was 5.25:1 in the Cohen-Salmon et al. (12) study. Our case was a 74 -year-old male smoker.

The clinical signs are related to tumor localization (1). Cabarcos et al. (13) have reported the most common clinical sign as a cough and chest pain in their series of 48 pulmonary adenocarcinoma patients while other findings were "wheezing" due to bronchial obstruction, dyspnea, obstructive pneumonia or atelectasis. The radiological findings are nonspecific and similar to other pulmonary carcinomas (7). Bull et al. (14) have reported the endoscopic appearance in cases with a tumor extending endobronchially as a finger-like intraluminal extension. Our case had clinical symptoms of shortness of breath and a dry cough and the respiratory sounds were decreased on physical examination. The mass had obstructed the left lower lobe bronchus on bronchoscopy.

The value of preoperative diagnostic tests in defining the tumor is limited. Only one component of the tumor is seen during biopsy for centrally-located tumors while it may not be possible to reach peripherally-located tumors on bronchoscopy. Sputum cytology, bronchoscopic and transthoracic fine needle biopsy (TBFNAB) can sometimes aid the diagnosis. The chance of making a preoperative diagnosis with bronchoscopic biopsy or TBFNAB depends on endobronchial localization of the tumor. It is reported that TBFNAB can provide a diagnosis in large lesions that are located peripherally (13). The bronchoscopic biopsy performed first in our case contained necrosis in most areas. The focal area neighboring the necrosis showed atypical pleomorphic cell groups that did not form definite patterns and these cells were positive with vimentin and negative with keratin. Following surgical resection, we saw that these cell groups belonged to one component of the tumor. The information above demonstrates the need to be careful when material with such features is encountered in biopsy material and to keep in mind the possibility of a biphasic tumor.

It is difficult to differentiate pulmonary carcinosarcoma from spindle cell carcinoma or blastoma and sarcoma metastatic to the lung with microscopy. Immunohistochemical investigations and/or electron microscopic findings play an important role in the differential diagnosis (15). The definite diagnosis depends on histopathological and immunohistochemical findings (16). It is reported that diagnosis can only be possible with multiple biopsies for cases with an endobronchial localization (14). The macroscopic appearance of the tumor has been found to change depending on necrosis and hemorrhage (7). Peripheral tumors are usually larger than $5 \mathrm{~cm}$, have welldefined borders and a grey, yellow or cream-colored section surface and a mucoid or hemorrhagic consistency with prominent necrosis (1). Cases with a dominant sarcoma component have a solid consistency and grey color while those with a dominant carcinoma component are soft and friable (7). The most common epithelial component is the squamous cell carcinoma $(45-70 \%)$ followed by adenocarcinoma $(31 \%)$ and adenosquamous carcinoma $(19 \%)(1,8)$. The sarcomatous component usually consists of rhabdomyosarcoma, chondrosarcoma, osteosarcoma or a combination of these elements (15). The section surface of the tumor in our case was yellow-white and contained occasional necrotic areas. Histologically, most of the tumor consisted of a sarcomatous component. The sarcomatous areas consisted of tumoral cells with occasional spindle character and focal chondroid differentiation areas and the carcinomatous areas had a morphological appearance consistent with squamous cell carcinoma and focal adenocarcinoma.

The most important prognostic parameter in sarcomatoid carcinomas is the tumor stage. They have a worse prognosis than classical non-small cell carcinomas even when grouped according to stage. It has been reported that adjuvant chemotherapy and radiotherapy are not helpful (1). The tumor has a marked tendency for distant metastasis and has a high rate of local recurrence. Postoperative survival is 9 months on average (15). However, tumors with an endobronchial localization have been reported to have a better prognosis than peripherally located cases as they cause earlier symptoms (17). There was no metastasis in the case we presented who is in his postoperative 9th month. $\mathrm{He}$ is still in good general condition and is being followed up.

In conclusion, pulmonary carcinosarcoma is a quite rare lung tumor. Finding tumor cell groups and performing advanced investigations are relatively easier on resection material than biopsy. However, it is a tumoral lesion where one must take into account the possibility of encountering small biopsy material that may contain only one component, which is usually the mesenchymal component. 


\section{REFERENCES}

1. Corrin B, Chang YL, Rossi G, Koss MN, Geisinger K, Wick MR, Nappi O, Finkelstein SD, Nakatani Y: Sarcomatoid Carcinoma. In: Travis WD, Brambilla E, Müller-Hermelink HK, Harris CC (eds). Pathology \& Genetics: Tumours of the Lung, Pleura, Thymus and Heart. Lyon, IARC Press, 2004, 53-58

2. Rossi G, Cavazza A, Sturm N, Migaldi M, Facciolongo N, Longo L, Maiorana A, Brambilla E: Pulmonary carcinomas with pleomorphic, sarcomatoid, or sarcomatous elements: a clinicopathologic and immunohistochemical study of 75 cases. Am J Surg Pathol 2003, 27:311-324

3. Nakajima M, Kasai T, Hashimoto H, Iwata Y, Manabe $\boldsymbol{H}$ :Sarcomatoid carcinoma of the lung: a clinicopathologic study of 37 cases. Cancer 1999, 86:608-616

4. Chang YL, Lee YC, Shih JY, Wu CT: Pulmonary pleomorphic (spindle) cell carcinoma: peculiar clinicopathologic manifestations different from ordinary non-small cell carcinoma. Lung Cancer 2001, 34:91-97

5. Raveglia F, Mezzetti M, Panigalli T, Furia S, Giuliani L, Conforti S, Meda S: Personal experience in surgical management of pulmonary pleomorphic carcinoma. Ann Thorac Surg 2004, 78:1742-1747

6. Wick MR, Ritter JH, Humphrey PA: Sarcomatoid carcinomas of the lung: a clinicopathologic review. Am J Clin Pathol 1997, 108:40-53

7. Balkanlı K, Işıtmangil T, Dakak M: Pulmoner karsinosarkom. Solunum Hastalık 1999, 10:284-289

8. Koss MN, Hochholzer L, Frommelt RA: Carcinosarcomas of the lung: a clinicopathologic study of 66 patients. Am J Surg Pathol 1999, 23:1514-1526
9. Blaukovitsch M, Halbwedl I, Kothmaier H, Gogg-Kammerer M, Popper HH: Sarcomatoid carcinomas of the lung--are these histogenetically heterogeneous tumors? Virchows Arch 2006, 449:455-461

10. Yazıcı Ü, Taştepe İ, Gülhan E, Ege T, Demiră̆ F, Kaya S, Altınok T: Pulmonary carcinosarcomas: an evaluation of seven patients. Turkish J Thorac Cardiovasc Surg 2009, 17:36-39

11. Takeda S, Nanjo S, Nakamoto K, Imachi T, Yamamoto S: Carcinosarcoma of the lung. Report of a case and review of the literature. Respiration 1994, 61: 113-116

12. Cohen-Salmon D, Michel RP, Wang NS, Eddy D, Hanson R: Pulmonary carcinosarcoma and carcinoma: report of a case studied by electron microscopy, with critical review of the literature. Ann Pathol 1985, 5:115-124

13. Cabarcos A, Gomez Dorronsoro M, Lobo Beristain JL: Pulmonary carcinosarcoma: a case study and review of the literature. Br J Dis Chest 1985, 79: 83-94

14. Bull JC Jr, Grimes OF: Pulmonary carcinosarcoma. Chest 1974, 65:9-12

15. Kim HM, Shin BS, Song YW, Lee SM, Jung SH, Kim CW, Kang KM, Jung IS, Na DJ: A case of pulmonary carcinosarcoma with persistent mild fever. Korean J Intern Med. 2002, 17:78-82

16. Ferrando C, Piédrola G, Pérez-Rodriguez E, Fogué L, Zapatero J, Flandes J, Martín-Aresti J: Gigant carcinosarcoma. Respiration 1992, 59:351-354

17. Meade P, Moad J, Fellows D, Adams CW: Carcinosarcoma of the lung with hypertrophic pulmonary osteoarthropathy. Ann Thoracic Surg 1991, 51:488-490 